\title{
S82. Proffered paper: In-vivo testing of PSMA-targeted T-cell immunotherapy for prostate cancer
}

\author{
Z Liu*, SB Papa, J Morris, J Maher \\ From 1st Immunotherapy of Cancer Conference (ITOC1) \\ Munich, Germany. 12-14 March 2014
}

\section{Introduction}

Bone is the most common site for metastasis in human prostate cancer patients. Skeletal metastases are a significant cause of morbidity and mortality and overall greatly affect the quality of life of prostate cancer patients. Despite advances in our understanding of the biology of primary prostate tumours, our knowledge of how and why secondary tumours derived from prostate cancer cells preferentially localise in bone remains limited. Examining the impact of these facets of bone metastasis in vivo remains a significant challenge, as animal models that closely mimic the natural history and malignant progression of clinical prostate cancer are not available.

\section{Objectives}

To develop an animal model of human metastatic prostate cancer. Once a model has been developed and optimised, it was this to test efficacy of immunotherapy using $\mathrm{T}$-cells that have been genetically targeted against prostate-specific membrane antigen (PSMA).

\section{Material and methods}

Using PCR, western blot, flow cytometry and ELISA, we performed functional anaylsis of fucosyltransferase 3 (FT3) in PC3LN3(PL)and PC3LN3-PSMA (PLP) tumour cell lines. In vivo bioluminescent imaging (BLI) was used to detect metastases.

\section{Results}

In preliminary studies, we have observed that delivery of a FT3-encoding retroviral vector to PL and PLP enables them to express sialyl Lewis $\mathrm{X}$ and to acquire E-selectin

\footnotetext{
Kings College London and Guys and St Thomas' NHS Foundation Trust,
} Cancer Studies, London, UK

(c) 2014 Liu et al; licensee BioMed Central Ltd. This is an Open Access article distributed under the terms of the Creative Commons Biomed Central Attribution License (http://creativecommons.org/licenses/by/2.0), which permits unrestricted use, distribution, and reproduction in any medium, provided the original work is properly cited. The Creative Commons Public Domain Dedication waiver (http:// creativecommons.org/publicdomain/zero/1.0/) applies to the data made available in this article, unless otherwise stated. binding activity. We also showed that FT3 promotes increased PLP motility and invasiveness in vitro. Bioluminescent animal model of metastasised prostate cancer is established to determine the effect of this upon their pattern of metastatic spread in SCID Beige mice.

\section{Conclusion}

We have established an in-vivo model of PSMA-expressing prostate cancer. This will serve as a platform to test immunotherapy using P28z+ T-cells.

Published: 12 March 2014

doi:10.1186/2051-1426-2-S2-I20

Cite this article as: Liu et al: S82. Proffered paper: In-vivo testing of

PSMA-targeted T-cell immunotherapy for prostate cancer. Journal for ImmunoTherapy of Cancer 2014 2(Suppl 2):120. and take full advantage of:

- Convenient online submission

- Thorough peer review

- No space constraints or color figure charges

- Immediate publication on acceptance

- Inclusion in PubMed, CAS, Scopus and Google Scholar

- Research which is freely available for redistribution 